\title{
Congenital pulmonary sequestration
}

INSERM

\section{Source}

INSERM. (1999). Orphanet: an online rare disease and orphan drug data base. Congenital pulmonary sequestration. ORPHA:3161

Cong enital pulmonary sequestration is a rare respiratory malformation characterized by a cystic or solid mass of nonfunctioning primitive segmental lung tissue that does not communicate with the tracheobronchial tree and has anomalous systemic blood supply. Intralobar pulmonary sequestration may be asymptomatic or may present with recurrent pulmonary infections, hemoptysis, chest pain, cough and is usually diagnosed in older children and adults. Extralobar pulmonary sequestration present with respiratory distress, cyanosis, difficulty feeding or infection, may be associated with other anomalies and is mostly diagnosed in neonates or infants. 